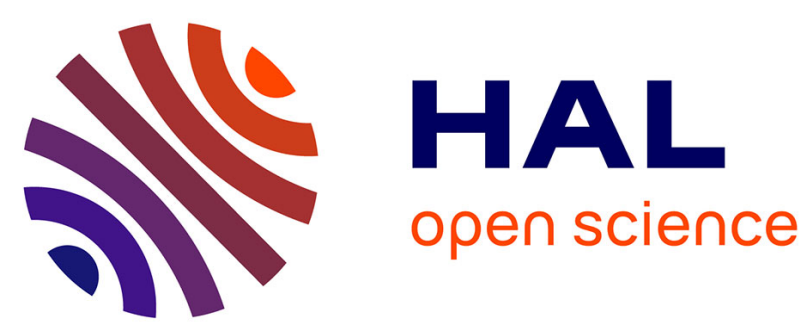

\title{
SUBSHELL SELECTIVE ELECTRON CAPTURE IN COLLISION OF O4+ WITH H2 AT $40 \mathrm{keV}$
}

\author{
A. Salmoun, T. Bouchama, S. Martin, M. Druetta
}

\section{To cite this version:}

A. Salmoun, T. Bouchama, S. Martin, M. Druetta. SUBSHELL SELECTIVE ELECTRON CAPTURE IN COLLISION OF O4+ WITH H2 AT 40 keV. Journal de Physique Colloques, 1989, 50 (C1), pp.C1-353-C1-356. 10.1051/jphyscol:1989140 . jpa-00229338

\section{HAL Id: jpa-00229338 https://hal.science/jpa-00229338}

Submitted on 1 Jan 1989

HAL is a multi-disciplinary open access archive for the deposit and dissemination of scientific research documents, whether they are published or not. The documents may come from teaching and research institutions in France or abroad, or from public or private research centers.
L'archive ouverte pluridisciplinaire HAL, est destinée au dépôt et à la diffusion de documents scientifiques de niveau recherche, publiés ou non, émanant des établissements d'enseignement et de recherche français ou étrangers, des laboratoires publics ou privés. 
SUBSHELL SELECTIVE ELECTRON CAPTURE IN COLLISION OF $\mathrm{O}^{4}+$ WITH $\mathrm{H}_{2}$ AT $40 \mathrm{keV}$

A. SALMOUN, T. BOUCHAMA, S. MARTIN and M. DRUETTA

Universite de Lyon I, Laboratoire de Spectrometrie Ionique et Moléculaire, CNRS LA-171, Campus de la Doua, F-69622 Villeurbanne Cedex, France

\section{Résumé :}

La collision d'échange de charge entre des ions $0^{4+}$ de $40 \mathrm{kev}$ et de l'hydrogène moléculaire a été observée par spectroscople optique dans l'u.v.. En plus des transitions entre états doublets avec coeur $1 s^{2} 2 s^{2}$, les transitions entre états doublets et quadruplets avec coeur $1 s^{2} 2 s 2 p$ ont été observées. Les niveaux $n=3$ de OIV sont préférentlellement peuplés. Les sections efficaces absolues ont été mesurèes.

\section{Abstract :}

u.v. photon spectroscopy of charge exchange collision between $0^{4+}(40 \mathrm{kev})$ ions and $\mathrm{H}_{2}$ has been observed. In addition to the transitions between doublet states with $1 s^{2} 2 s^{2}$ core, transitions between doublet and quartet states with $1 s^{2} 2 s 2 p$ core have been observed $n=3$ levels of 0 IV are selectively populated. Absolute cross sections have been measured.

\section{Collision between $0^{4+}$ and $H_{2}$ has been analysed by photon spectroscopy}

The experimental apparatus has been described in previous papers (1) (2). The $0^{4+}$ ion beam extracted from the electron cyclotron resonance source is charge and mass analysed by two bending magnets and finally sent into a gas cell with a $8 \mathrm{~mm}$ diameter entrance hole. The pressure is kept at $5 \times 10^{-5} \mathrm{mbar}$ and typical beam intensity is $8 \mu \mathrm{A}$ at $40 \mathrm{keV}$ energy.

Light emitted during the collision is observed at $25^{\circ}$ of the beam direction with a grazing incidence spectrometer equipped with a 600 lines $/ \mathrm{mm}$ grating blazed at $25.6 \mathrm{~nm}$. The photon detection is made by $\mathrm{MgF}_{2}$ coated microchannels plates (MCP).

The absolute cross-section calibration of our experimental set-up has been realized insitu with the three $C$. IV lines $\left(\lambda=31.2 \mathrm{~nm} 2 s^{2} S-3 p^{2} p^{0}, \lambda=38.4 \mathrm{~nm} 2 p^{2} p^{0}-3 d^{2} D, \lambda=41.9 \mathrm{~nm} 2 p^{2} p^{0}-3 s^{2} S\right)$ obtained by the $\mathrm{C}^{4+}+\mathrm{H}_{2}$ collision at $40 \mathrm{keV}$ and for wich the emission cross-sections have been measured (3). By this method we only have measure the ion beam currents in the vacuum. During the experiment we have only to take into account the small instabilities of the ion current (after passage through the gas). We also use as secondarty etalons, collisions like $\mathrm{N}^{6+}, \mathrm{O}^{6+}, \mathrm{N}^{5+}, \mathrm{N}^{6+}+\mathrm{He}\left(\mathrm{H}_{2}\right)$ for which emission cross-sections have been measured and which cover a wide spectral range. A conservative value of the error bar on emission cross-sections may be then evaluated to $30 \%$. Of course for intense lines where the photon statistic is good, this error bar may be better. This estimated error bar does not include any possible polarization effect of the emitted radiations. 
A typical spectrum recorded during the $\mathrm{O}^{4+}+\mathrm{H}_{2}$ collision at $40 \mathrm{kev}$ is displayed on figure 1. 0 IV lines belong to transitions with the upper state either in the $1 s^{2} 2 s^{2} n \ell$ configuration or in the $1 s^{2} 2 s z p n^{\prime} \ell^{\prime}$ configuration. They are interpreted as the result of the single electron charge exchange collision between $0^{4+}$ in the fondamental $1 s^{2} 2 s^{2}$ is state or in the matastable $1 s^{2} 2 s 2 p$ state and $H_{2}$. The $1 \mathrm{~s}^{2} 2 \mathrm{~s} 2 \mathrm{p}$ state has a lifetime of $0.51 \mathrm{~ms}$ (4) compatible with the time of flight of the ions from eht ECR source to the observation cell. Brazuk et al. (5) have measured by a method of beam attenuation the metastable $0^{4+}$ beam fraction in an ECR source. Their value of $42 \%$ will be taken in our work in order to determine the cross-section values. Two weak lines at 62.9 and $77.96 \mathrm{~nm}$ may be interpreted as the $2 s 2 p^{2}{ }^{4} p-2 p^{3} 4 s^{*}$ and $2 s 2 p^{2} 2 D-2 p^{32} D^{\circ}$ transitions. We also observe the $\lambda 55.4 \mathrm{~nm} 2 s^{2} 2 p^{2} p^{\cdot}-2 s 2 p^{2} 2 p, \lambda$ $60.8 \mathrm{~nm} 2 \mathrm{~s}^{2} 2 \mathrm{p}^{2} \mathrm{p}^{\cdot}-2 \mathrm{~s} 2 \mathrm{p}^{2} 2 \mathrm{~s}, \lambda 78,7-79,0 \mathrm{~nm} 2 \mathrm{~s}^{2} 2 \mathrm{p}^{2} \mathrm{p}^{\cdot}-2 \mathrm{~s} 2 \mathrm{p}^{2} 20$ transitions.

Some weak lines of $0111(\lambda 22.8-29.5-35.9-37.4-39.6 \mathrm{~nm})$ are also observed. They are due to double collision or/and double capture process.

The emission cross-sections $\sigma_{e m}$ of the observed $O$ IV lines are reported in Table $I$ and II. Capture from the $0^{4+} 1 s^{2} 2 s^{2}$ core is selective on the $n=3$ doublets levels. With the $0^{4+} 1 s^{2} 2 s 2 p$ core the capture is also selective on the $n=3$ doublet and quadruplet levels. These results are in agreement with the results of the reaction window of the Extended Classical BarrierModel (ECBM) (6).

The total $\sum \sigma(n)$ excitation cross-section $( \pm 30 \%)$ is found $317 \times 10^{-17} \mathrm{~cm}^{2}$ for the

ne

$1 \mathrm{~s}^{2} 2 \mathrm{~s}^{2}$ core, and $280 \times 10^{-17} \mathrm{~cm}^{2}$ for the $1 \mathrm{~s}^{2} 2 \mathrm{~s} 2 \mathrm{p}$ core. These values are to be compare to the $\sigma_{\mathbf{q} \rightarrow \mathbf{q}-1}$ $(298 \pm 4) 10^{-17} \mathrm{~cm}^{2}$ of Phaneuf et al. obtained with a PIG source, at the same energy, but without discrimination against the metastable beam fraction. These results seems to prove that the capture cross--section from the metastable state is of the same magnitude than the capture cross-section from the fondamental state.

This experiment was carried out at the LAGRIPPA, CEA-CNRS.

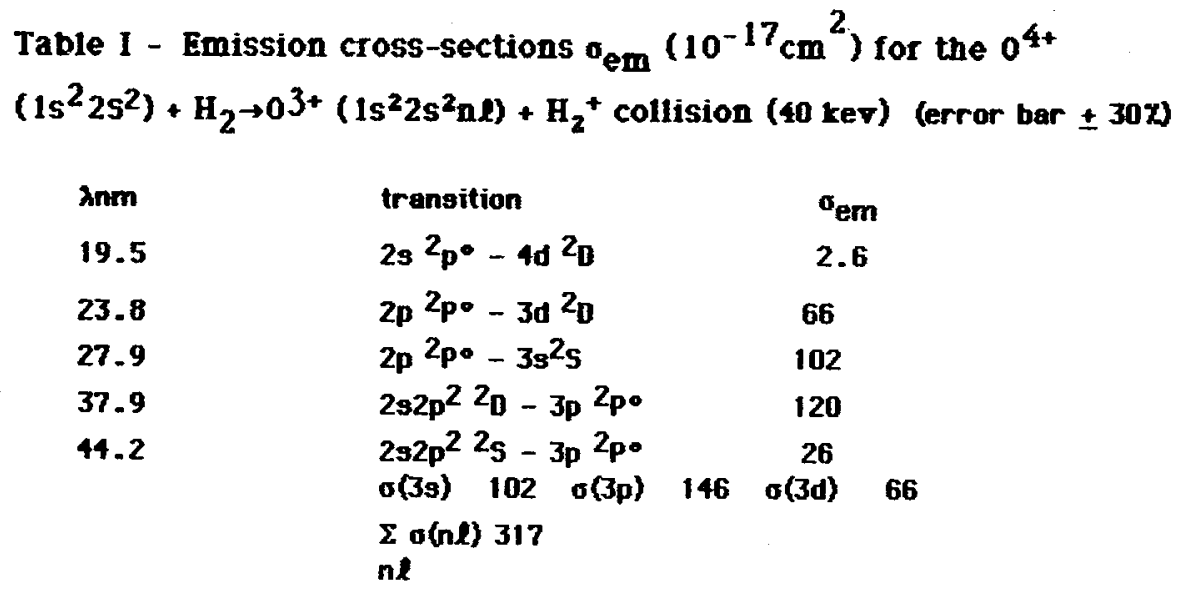


Table II - Emission cross-sections om $\left(10^{-17} \mathrm{~cm}^{2}\right)$ for the $0^{4+}\left(1 \mathrm{~s}^{2} 2 \mathrm{~s} 2 \mathrm{p}\right)$

$+\mathrm{H}_{2} \rightarrow \mathrm{O}^{3+}\left(1 \mathrm{~s}^{2} 2 \mathrm{~s} 2 \mathrm{pnl}\right)+\mathrm{H}_{2}+$ collision (40 kev) (error bar $\left.\pm 30 \mathrm{x}\right)$

\begin{tabular}{|c|c|c|}
\hline$\lambda n m$ & transition & $\sigma_{\mathrm{em}}$ \\
\hline 20.10 & $2 s 2 p^{2} 4 p-4 s 4 p$ & 2.8 \\
\hline 20.29 & $2 s^{2} 2 p^{2} p \cdot-3 p^{2} s$ & 4.7 \\
\hline 20.73 & $2 s^{2} 2 p^{2} p^{0}-3 p^{2} D$ & 47 \\
\hline 21.41 & $2 s^{2} 2 p^{2} p^{0}-3 p^{2 p}$ & 24 \\
\hline 23.11 & $2 s^{2} 4 p-3 d^{4} p$ & 8.3 \\
\hline 23.35 & $2 s 2 p^{2} 4 p-3 d^{4} p^{0}$ & 16 \\
\hline 26.05 & $2 s 2 p^{2} 2 p-3 d^{2} F^{\circ}$ & 7.4 \\
\hline 26.68 & $2 s 2 p^{2} 2 D-3 d^{2} D^{\circ}$ & 5.8 \\
\hline 27.22 & $2 s 2 p^{2} 4 p-3 s^{4} p$ & 131 \\
\hline 28.58 & $2 s 2 p^{2} 2 s-3 d^{2} p \cdot$ & 1.8 \\
\hline 29.92 & $2 s 2 p^{2} 2 p-3 d^{2} p$ & 0.2 \\
\hline 30.68 & $2 s 2 p^{2} 2 p-3 s^{2} p$ & 21 \\
\hline 31.16 & $2 s 2 p^{2} 2 p-3 s^{2} p$ & 2 \\
\hline 34.65 & $2 s 2 p^{2} 2 s-3 s^{2} p^{0}$ & 7.4 \\
\hline 36.72 & $2 s 2 p^{2} 2 p-3 s^{2} p$ & 2 \\
\hline 55.36 & $2 s^{2} 2 p^{2} p \cdot-2 s 2 p^{2} p$ & 12 \\
\hline
\end{tabular}

\section{REFERENCES}

1/ S.MARTM, Y.DRUETTA and J.DESESQUEL.J.S. Muc1.Inst.Meth. B.14 (1986) 254.

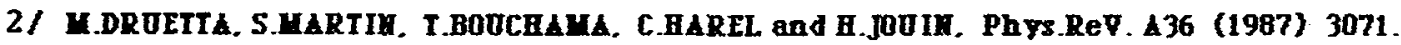

3/ D.DIJKKAMP, 1985, Thesis, Utreckt University. 


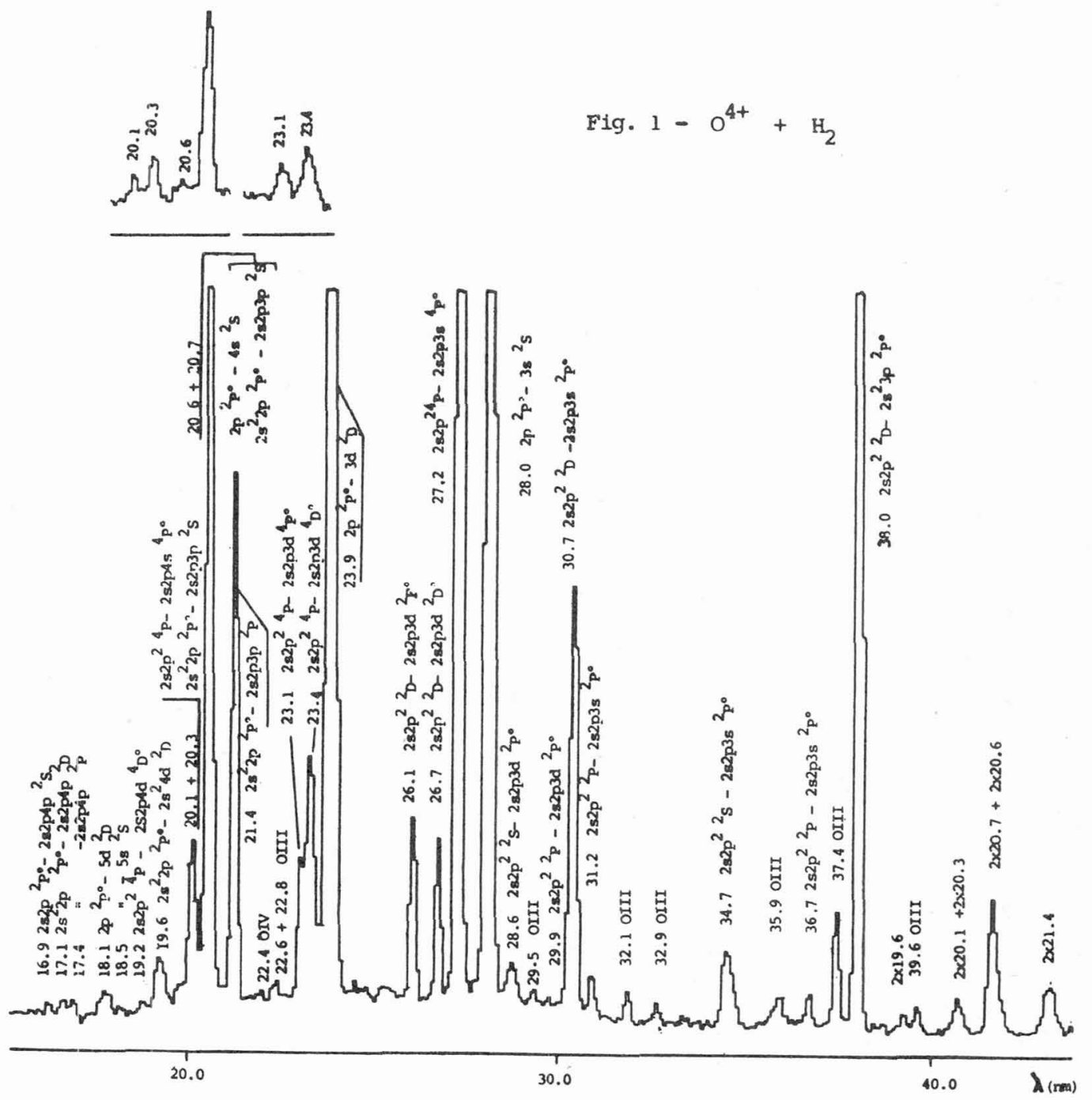

$4 /$ K.T.CHEHG, T.K.KIM and J.P.DESCLAUY, At. Jata, Hucl.Data Tables 24 (1979) 111.

$5 /$ A.BRAZUE, D.DIJKKAMP, A.G.DRERTJ, F.J.DE HEER and H.VIHTER, J.PhYS.B AT. Yol.Phy. 17 (1984) 2489.

6/ A.HIELUSS. J.Phys.B At.Yot.Phys. 19 (1986) 2925.

$7 /$ R.A.PHAHEUY, I.ALVAREZ, F.M.YEFD and D.H.CRAHDALL, PhT.ReV. A 26 (1982) 1892. 